\title{
Prevalence of Anemia in Pediatric Patients According to Asthma Control: Propensity Score Analysis
}

\author{
Ji-Eun Chang \\ Hyang-Mi Lee \\ Jongyoon $\mathrm{Kim}$ (D) \\ Kiyon Rhew $\mathbb{D}$ \\ College of Pharmacy, Dongduk Women's \\ University, Seoul, Republic of Korea
}

Correspondence: Kiyon Rhew

College of Pharmacy, Dongduk Women's University, 60 Hwarang-ro I3-gil,

Seongbuk-gu, Seoul, 02748, Republic of Korea

Tel +82-2-940-4519

Fax +82-2-940-4159

Email kiyon@dongduk.ac.kr
Purpose: To investigate whether the degree of asthma control is associated with anemia in pediatric patients.

Patients and Methods: A cross-sectional study was performed using a dataset from the Health Insurance Reviews \& Assessment Service (HIRA) of South Korea in 2016, which included children and adolescent patients diagnosed with asthma. Binary logistic regression was used to assess the association between asthma control and the prevalence of anemia.

Results: A total of 236,429 patients under 18 years old were included in the study, including 233,975 patients with controlled and 2454 with uncontrolled asthma. Binary logistic regression after adjustment for confounding factors showed that patients with uncontrolled asthma had a 2.64-fold higher prevalence of anemia than those with well-controlled asthma (OR = 2.64, 95\% CI: 2.16-3.22). While there was no effect of gender on the results, there was a statistically significant association between the prevalence of anemia and asthma control in patients under 13 years old.

Conclusion: These findings suggest that the prevalence of anemia is inversely correlated with asthma control in pediatric patients. Further studies are necessary to obtain pathophysiological insight into the relationship between severe inflammatory diseases and anemia.

Keywords: pediatric, asthma, anemia, anemia of inflammation, iron deficiency anemia

\section{Introduction}

Anemia in children is generally defined as a hemoglobin concentration less than the 5th percentile for age. ${ }^{1}$ Chronic inflammatory diseases are thought to generate anemia of inflammation (AI). Several studies suggest that up to $40 \%$ of all anemias worldwide can be considered AI or combined anemias with important AI contributions. $^{2,3}$ This causes an impairment of the immune-mediated regulation of hepcidin and several cytokines, which play a major role in iron homeostasis, accelerate the turnover of red blood cells (RBC), and affect the activity of erythropoietin (EPO), thereby reducing hemoglobin and iron levels. ${ }^{4-7}$ The prevalence of $\mathrm{AI}$ is high in patients with systemic infection, inflammatory disease, or malignancy. ${ }^{4,8-12}$ Old age can also be a risk factor for inflammatory anemia. ${ }^{13,14}$

Iron deficiency anemia (IDA), which accounts for the highest prevalence of anemia, exhibits low iron and hemoglobin levels as in AI, and there is no single way to differentiate between AI and IDA. ${ }^{15,16}$ Therefore, it is difficult to distinguish between the two types of anemia to diagnose anemia in patients in clinical settings. Nevertheless, it is important to evaluate the underlying disease (or risk factors) and hematologic characteristics of the patients to distinguish IDA from AI since these two diseases have different treatment approaches. ${ }^{4}$ 
Asthma is one of the common allergic diseases caused by a disturbance of the immune system, ${ }^{5}$ and this chronic inflammatory condition can cause systemic inflammation. ${ }^{6}$ Asthma also has a high prevalence in pediatric patients, unlike other chronic inflammatory diseases. ${ }^{17,18}$ Both anemia and asthma are high-prevalence diseases in children and have a negative impact on children's growth, comorbidities, and health-related quality of life. ${ }^{19-21}$ Several studies have recently shown the association of asthma with the increased prevalence of anemia. ${ }^{22-24}$ Previous studies reported that not only asthma, but also atopic dermatitis, allergic rhinitis, and food allergies were correlated with the prevalence of anemia. ${ }^{22-24}$ No studies, however, have been conducted on whether severe or uncontrolled asthma could increase the prevalence of anemia.

We hypothesized that patients with uncontrolled asthma were more likely to have an active inflammatory condition, which may increase the prevalence of anemia. In a previous study, the correlation between asthma and anemia in children was more pronounced than in adults and elderly patients. ${ }^{24}$ This led us to consider the association between atopic disease and AI in pediatric patients in a clinical setting. Therefore, this study aimed to evaluate whether the prevalence of anemia in pediatric asthma patients differed according to asthma control.

\section{Patients and Methods}

\section{Study Subjects}

Nearly all (98\%) Koreans are enrolled in the universal health insurance system, and all medical information is reported to the Health Insurance Review \& Assessment Service (HIRA). In this study, $10 \%(\sim 1,100,000)$ of the patients under the age of 20 provided by the HIRA were analyzed using a dataset constructed by random stratification based on age and sex (HIRA-PPS-2016). ${ }^{25}$ The sample dataset provided by HIRA is cross-sectional claims data and is provided after removing the patient's personal identifiable information in accordance with the personal information protection regulations of Korea. We included patients younger than 18 years and patients prescribed asthma medications with a diagnosis of asthma. Patients diagnosed with anemia other than IDA or AI were excluded. The Korean Standard Classification of Disease and Cause of Death-7 (KCD-7) was used for disease diagnosis.

\section{Definition of Disease}

In South Korea, since diagnostic codes must be entered when prescribing medication or a procedure and there is no refill system, there are no missing values for claims data. Patients diagnosed with asthma (J45.X) and/or worsening asthma (J46. $\mathrm{X}$ ) and who were prescribed asthma medications were defined as asthma patients. We classified the uncontrolled asthma group as those with frequent exacerbations ( $\geq 2 /$ year) requiring oral corticosteroids (OCS), and/or serious exacerbations requiring hospitalization exacerbation of at least once a year, and the remaining were defined as the controlled asthma group. KCD-7 codes are based on the International Classification of Diseases (ICD)-10, modified and supplemented to suit the prevalence of diseases in Korea. IDA and AI were defined as D50.X and D63.8 respectively, and medication for asthma is shown in Table 1.

\section{Confounders}

We used confounding factors to analyze the association between the prevalence of atopic disease and anemia that were used in our previous study (Table 2). ${ }^{23}$ These diseases were extracted based on previous studies suggesting that the prevalence of IDA/AI could be increased. The patient's age, health insurance type and sex were included in the confounding factors.

\section{Statistical Analysis}

Binary logistic regression was carried out by applying inverse probability of treatment weighting (IPTW) using the propensity score. To calculate the propensity score, we used a multivariable logistic regression model to estimate the probability of each patient, including confounders. After applying the propensity score weights, the evaluation of the disturbance factors in the two groups was made with the variance ratio. The closer the variance ratio is to 1.0 , the similar the characteristics of the two groups. The disturbing factor characteristics in the two groups were evaluated as statistically similar when the variance ratio ranged from 0.5 to $2.0 .{ }^{26}$ Odds ratio (OR) with 95\% confidence interval (CI) were reported for the association between anemia and asthma severity. Subgroup analysis was performed according to age group (children: under 13 years old, adolescents: 13 years or older and under 18 years old), gender, and types of health insurance. All statistical analyses were conducted using SAS 9.4 (SAS Institute Inc., Cary, NC, USA). This study was approved by the Institutional Review Board of Dongduk Women's University (IRB No. DDWU2008-01). 
Table I The List of ATC Codes of Asthma Medication in the Study

\begin{tabular}{|c|c|c|}
\hline Category & Medication & ATC Code \\
\hline Selective beta-2-adrenoreceptor agonists & $\begin{array}{l}\text { Salbutamol } \\
\text { Fenoterol } \\
\text { Tulobuterol } \\
\text { Formoterol } \\
\text { Clenbuterol } \\
\text { Procaterol } \\
\text { Indacaterol }\end{array}$ & $\begin{array}{l}\text { R03AC02 } \\
\text { R03AC04 } \\
\text { R03ACII } \\
\text { R03ACI3 } \\
\text { R03ACI4 } \\
\text { R03ACI6 } \\
\text { R03ACI8 }\end{array}$ \\
\hline $\begin{array}{l}\text { Adrenergics in combination with corticosteroids or other drugs, } \\
\text { excl. anticholinergics }\end{array}$ & $\begin{array}{l}\text { Salmeterol and fluticasone } \\
\text { Formoterol and budesonide } \\
\text { Formoterol and beclometasone } \\
\text { Vilanterol }\end{array}$ & $\begin{array}{l}\text { R03AK06 } \\
\text { R03AK07 } \\
\text { R03AK08 } \\
\text { R03AKI0 }\end{array}$ \\
\hline $\begin{array}{l}\text { Adrenergics in combination with anticholinergics incl. triple } \\
\text { combinations with corticosteroids }\end{array}$ & $\begin{array}{l}\text { Vilanterol } \\
\text { Indacaterol and glycopyrronium bromide } \\
\text { Formoterol and aclidinium bromide } \\
\text { Olodaterol and tiotropium bromide }\end{array}$ & $\begin{array}{l}\text { R03AL03 } \\
\text { R03AL04 } \\
\text { R03AL05 } \\
\text { R03AL06 }\end{array}$ \\
\hline Glucocorticoids for obstructive airway disease, inhalants & $\begin{array}{l}\text { Beclometasone } \\
\text { Budesonide } \\
\text { Betamethasone } \\
\text { Fluticasone } \\
\text { Triamcinolone } \\
\text { Ciclesonide }\end{array}$ & $\begin{array}{l}\text { R03BA0I } \\
\text { R03BA02 } \\
\text { R03BA04 } \\
\text { R03BA05 } \\
\text { R03BA06 } \\
\text { R03BA08 }\end{array}$ \\
\hline Anticholinergics for obstructive airway disease, inhalants & $\begin{array}{l}\text { Ipratropium bromide } \\
\text { Tiotropium bromide } \\
\text { Aclidinium bromide } \\
\text { Glycopyrronium bromide } \\
\text { Umeclidinium bromide }\end{array}$ & $\begin{array}{l}\text { R03BB0I } \\
\text { R03BB04 } \\
\text { R03BB05 } \\
\text { R03BB06 } \\
\text { R03BB07 }\end{array}$ \\
\hline $\begin{array}{l}\text { Antiallergic agents, excl. corticosteroids for obstructive airway } \\
\text { disease, inhalants }\end{array}$ & $\begin{array}{l}\text { Bambuterol } \\
\text { Clenbuterol and ambroxol }\end{array}$ & $\begin{array}{l}\mathrm{R} 03 \mathrm{CCI} 2 \\
\mathrm{R} 03 \mathrm{CC} 63\end{array}$ \\
\hline Other systemic drugs for obstructive airway diseases & $\begin{array}{l}\text { Theophylline } \\
\text { Aminophylline } \\
\text { Theobromine } \\
\text { Doxofylline } \\
\text { Roflumilast } \\
\text { Betamethasone } \\
\text { Deflazacort } \\
\text { Dexamethasone } \\
\text { Fludrocortisone } \\
\text { Hydrocortisone } \\
\text { Methylprednisolone } \\
\text { Paramethasone } \\
\text { Prednisolone } \\
\text { Prednisone } \\
\text { Triamcinolone }\end{array}$ & $\begin{array}{l}\text { R03DA04 } \\
\text { R03DA05 } \\
\text { R03DA07 } \\
\text { R03DAII } \\
\text { R03DX07 } \\
\text { H02AB0I } \\
\text { H02ABI3 } \\
\text { H02AB02 } \\
\text { H02AA02 } \\
\text { H02AB09 } \\
\text { H02AB04 } \\
\text { H02AB05 } \\
\text { H02AB06 } \\
\text { H02AB07 } \\
\text { H02AB08 }\end{array}$ \\
\hline
\end{tabular}


Table 2 The List of KCD-7 Diagnostic Codes of Diseases in the Study

\begin{tabular}{|c|c|c|}
\hline \multicolumn{2}{|l|}{ Category } & \multirow{2}{*}{$\begin{array}{l}\text { KCD-7 } \\
J 45 . X \\
J 46 . X\end{array}$} \\
\hline Asthma & $\begin{array}{l}\text { Asthma } \\
\text { Asthma exacerbation }\end{array}$ & \\
\hline Anemia & $\begin{array}{l}\text { Iron deficiency anemia } \\
\text { Anemia of inflammation }\end{array}$ & $\begin{array}{l}\text { D50.X } \\
\text { D63.8 }\end{array}$ \\
\hline \multicolumn{3}{|l|}{ Confounders } \\
\hline Systemic infection & $\begin{array}{l}\text { Meningitis } \\
\text { BJI } \\
\text { Sepsis }\end{array}$ & $\begin{array}{l}\text { A87.X, A39.X } \\
\text { M00.X, M0I.X, M02.X, M03.X } \\
\text { A40.X, A4I.X }\end{array}$ \\
\hline Hepatitis & & BI5.X, B।6.X, B।7.X, B।8.X, B।9.X \\
\hline CKD & & NI8.X \\
\hline $\mathrm{HF}$ & & $150 . X$ \\
\hline DM & & EI0.X, EII.X, EI2.X, EI3.X, EI4.X \\
\hline Mental disorder & $\begin{array}{l}\text { Depression } \\
\text { Anxiety }\end{array}$ & $\begin{array}{l}F 32 . X, F 33 . X \\
F 40 . X, F 4 I . X, F 93 . X, F 06.4\end{array}$ \\
\hline Chronic inflammation & $\begin{array}{l}\text { PUD } \\
\text { COPD } \\
\text { SLE } \\
\text { RA } \\
\text { IBD }\end{array}$ & $\begin{array}{l}\text { K25.X, K26.X, K27.X } \\
\text { J42.X, J43.X, J44.X } \\
\text { M32.X } \\
\text { M05.X, M06.X, M08.0 } \\
\text { K5I.X, K50.X }\end{array}$ \\
\hline Cancer & & CXX.X \\
\hline
\end{tabular}

Abbreviations: BJI, bone and joint infection, CKD, chronic kidney disease, HF, heart failure, DM, diabetes mellitus, PUD, peptic ulcer disease, COPD, chronic obstructive pulmonary disease, SLE, systemic lupus erythematosus, RA, rheumatoid arthritis, IBD, irritable bowel disease.

\section{Results}

\section{Patient Characteristics}

The HIRA-PPS-2016 dataset included 1,004,866 patients. A total of 236,429 patients were included in this study, excluding 148,459 patients over 18 years old, patients diagnosed with asthma and not prescribed asthma medication (610,323 patients), and patients diagnosed with anemia other than IDA/AI (9655 patients) (Figure 1). There were 233,975 patients in the controlled asthma group and 2454 in the uncontrolled asthma group. After IPTW, confounding factors were more similarly distributed in the two groups (Table 3). The variance ratio of all confounding diseases became close to 1 after IPTW application.

\section{Association Between Anemia and Asthma Control}

Even after adjustment for confounding factors, the prevalence of anemia (IDA/AI) was 2.64-times higher in patients with uncontrolled asthma compared to patients with well-controlled asthma (OR $=2.64,95 \% \mathrm{CI}: 2.16$ 3.22; $<<0.001$ ) (Table 4). The association was significant in both male pediatric patients ( $\mathrm{OR}=2.66,95 \%$ CI: 2.04 3.46; $\mathrm{p}<0.001)$ and female patients $(\mathrm{OR}=2.61,95 \% \mathrm{CI}$ : $1.92-3.56 ; \mathrm{p}<0.001)$. As a result of subgroup analysis according to age group, the prevalence of anemia was statistically significant only in patients under 12 years of age according to asthma control. In the analysis according to health insurance eligibility, the prevalence of anemia was higher in patients with uncontrolled asthma compared to those with asthma control in patients under the health insurance program (Table 5).

\section{Discussion}

The prevalence of anemia in the uncontrolled or severe asthma group was higher than that of the well-controlled and/or mild asthma patients. In this study, the effects of confounding factors other than asthma control were adjusted by propensity score weighting. In the previous study, the prevalence of anemia in children with asthma 


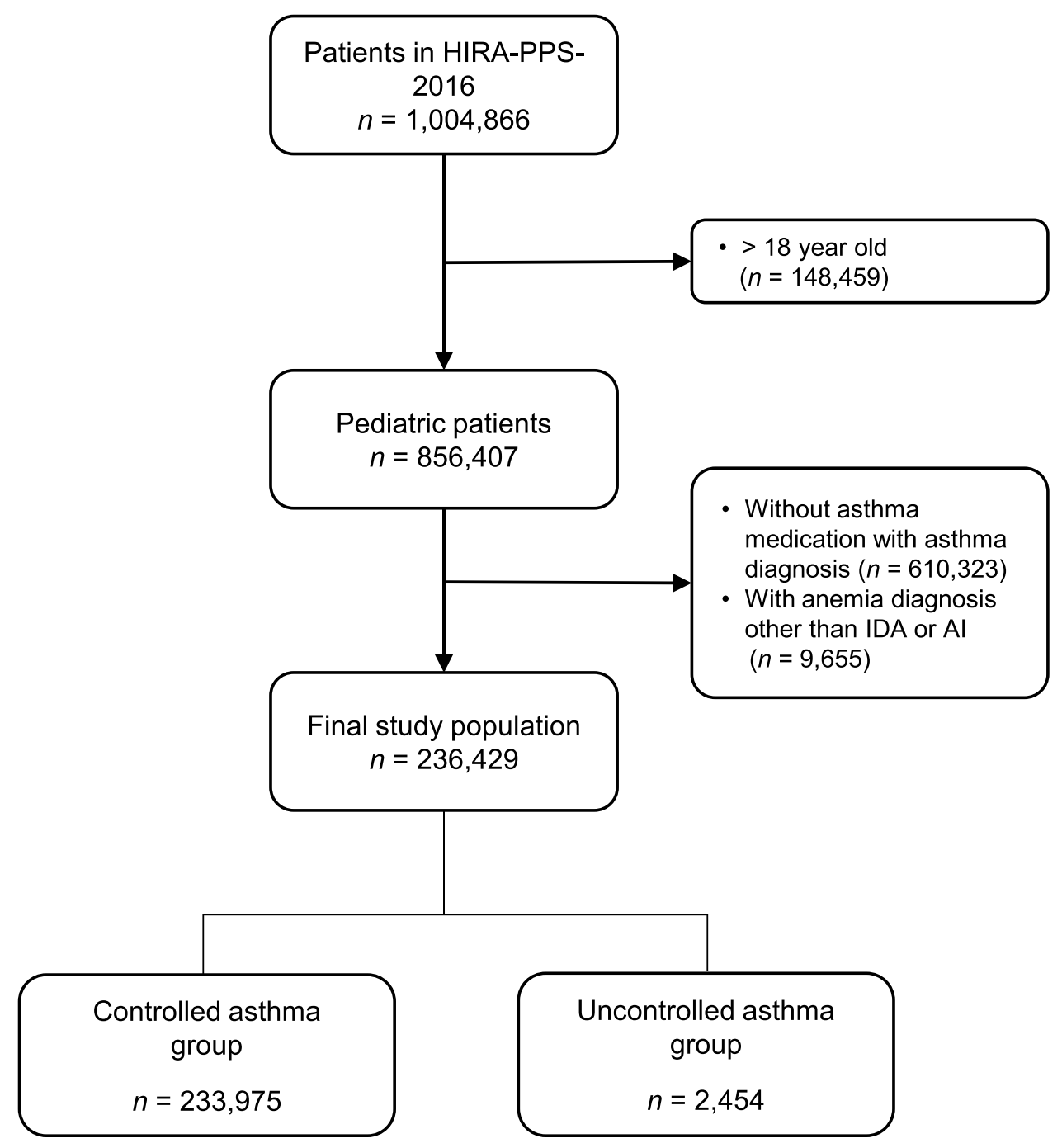

Figure I Flow diagram for study subject inclusion.

Abbreviations: HIRA, Health Insurance Review \& Assessment Service; IDA, iron deficiency anemia; Al, anemia of inflammation.

was found to be higher than those in children without asthma. Our research team, however, was able to show that uncontrolled asthma patients had a higher risk of anemia among pediatric asthma patients. The association between anemia and asthma control was not statistically significant in adolescents. The prevalence of anemia in adolescent asthma patients was lower than that of younger children. Dugdale's study suggested that adolescent patients had an anemia prevalence of about $6 \%$ in the developed country. ${ }^{27}$ About $2.1 \%$ of adolescent asthma patients were diagnosed with anemia in our study, which was very low compared to previous studies. According to Statistics Korea, when the age group was classified by 5 -year intervals, the average number of annual outpatient clinic visits per person for 15 to 19 -year-old patients was
8.3 , which was much lower than the average number of 18.0 among all ages. ${ }^{28}$ This might have been due to a reduced anemia diagnosis rate in the adolescent group. A subgroup analysis of patients in the medical aid program also showed no association between asthma control and anemia. In this group, the association between asthma prevalence and anemia was not revealed. ${ }^{24}$ This, as in the previous study, may also be a result of different patterns of use of medical service in the patients under medical aid program.

Regarding a relationship between pathophysiology of asthma and anemia, it is unclear how the immune responses in severe and/or uncontrolled asthma is associated with anemia development. A potential hypothesis is that heterogeneous cytokine milieu in the severe asthma 
Table 3 Baseline Characteristics of Subjects Before and After Inverse Probability of Treatment Weighting

\begin{tabular}{|c|c|c|c|c|}
\hline & \multicolumn{2}{|r|}{ Frequency, n (\%) } & \multicolumn{2}{|r|}{ Variance Ratio } \\
\hline & $\begin{array}{r}\text { Controlled Asthma Group } \\
(n=233,975)\end{array}$ & $\begin{array}{r}\text { Uncontrolled Asthma Group } \\
\qquad(n=2,454)\end{array}$ & Before Weighting & After Weighting \\
\hline Age group & & & 1.0989 & 0.9839 \\
\hline Children $(<12)$ & $203,369(86.92)$ & $2,344(95.52)$ & & \\
\hline Adolescents $(\geq 12,<18)$ & $30,606(13.08)$ & $110(4.48)$ & & \\
\hline Sex & & & 1.0432 & 1.0001 \\
\hline Male & I25,027 (53.44) & $\mathrm{I}, 368(55.75)$ & & \\
\hline Female & $108,948(46.56)$ & $\mathrm{I}, 086(44.25)$ & & \\
\hline Insurance Type & & & 0.9950 & 1.0000 \\
\hline Health insurance & $229,488(98.08)$ & $2,395(97.60)$ & & \\
\hline Medical aid & 4,487 (1.92) & $59(2.40)$ & & \\
\hline \multicolumn{5}{|l|}{ Systemic infection } \\
\hline Meningitis & $768(0.33)$ & $6(0.24)$ & 0.7448 & 0.9999 \\
\hline BJI & $224(0.10)$ & I $(0.04)$ & 0.4256 & 0.9940 \\
\hline Sepsis & $\mathrm{I}, 883(0.80)$ & $46(1.87)$ & 2.3291 & 0.9975 \\
\hline HEP & $\mathrm{I}, 367(0.58)$ & $4 \mathrm{I}(\mathrm{I} .67)$ & 2.8596 & 0.9987 \\
\hline CKD & $14(0.01)$ & I (0.04) & 6.8103 & 0.9998 \\
\hline HF & $294(0.13)$ & $6(0.24)$ & 1.9458 & 0.9820 \\
\hline DM & $988(0.42)$ & $14(0.57)$ & 1.3511 & 0.9906 \\
\hline \multicolumn{5}{|l|}{ Chronic inflammation } \\
\hline PUD & 3,839 (I.64) & $28(1.14)$ & 0.6954 & 0.9947 \\
\hline COPD & $6,201(2.65)$ & $67(2.73)$ & 1.0301 & 0.9973 \\
\hline SLE & $70(0.03)$ & $4(0.16)$ & 5.4484 & 0.9897 \\
\hline RA & $336(0.14)$ & $5(0.20)$ & 1.4188 & 0.9927 \\
\hline IBD & $81(0.03)$ & $2(0.08)$ & $2.354 I$ & 0.9998 \\
\hline Cancer & $322(0.14)$ & $2(0.08)$ & 0.5922 & 0.9893 \\
\hline \multicolumn{5}{|l|}{ Mental disorders } \\
\hline Depression & $727(0.31)$ & $8(0.33)$ & 1.0491 & 0.9954 \\
\hline Anxiety & I,697 (0.73) & $13(0.53)$ & 0.7304 & 1.0037 \\
\hline
\end{tabular}

Abbreviations: BJI, bone and joint infection, CKD, chronic kidney disease, HF, heart failure, DM, diabetes mellitus, PUD, peptic ulcer disease, COPD, chronic obstructive pulmonary disease, SLE, systemic lupus erythematosus, RA, rheumatoid arthritis, IBD, irritable bowel disease.

Table 4 Association Between Asthma Severity and Anemia in Pediatric Patients After Adjusting with Propensity Score Weighting

\begin{tabular}{|l|c|c|c|c|}
\hline Asthma Group & Anemia, n (\%) & OR (95\% Cl) & OR $_{\text {adj }}(\mathbf{9 5 \%} \mathbf{~ C l})$ & P value \\
\hline Controlled asthma & $9,818(4.20)$ & I [Reference] & I [Reference] & $<0.00 \mathrm{I}$ \\
Uncontrolled asthma & $355(14.47)$ & $3.86(3.45-4.33)$ & $2.64(2.16-3.22)$ & $<0.00 \mathrm{I}$ \\
\hline
\end{tabular}

Abbreviations: $\mathrm{OR}$, odds ratio; $\mathrm{OR}_{\mathrm{ad}}$, odds ratio after adjusting with propensity score weighting.

might be related to anemia development. Asthma is predominantly mediated by $\mathrm{T}$ helper 2 (Th2) or innate type 2 immune responses, which provides biomarkers and targets for therapeutics such as anti-IgE or anti-IL-5. ${ }^{29}$ Although less studied, emerging evidences suggest that a varying array of cytokines, derived from $\mathrm{T}$ cells and epithelial cells, is observed in conjunction with Th2 cytokines in patients with severe disease. Inflammatory cytokines including IL-17 or IFN $\gamma$ was reported to be more prevalent in chronic severe asthma than in mild or moderate 
Table 5 Association Between Asthma Severity and Anemia in Subgroups After IPTW

\begin{tabular}{|c|c|c|c|c|c|c|c|}
\hline \multicolumn{2}{|c|}{ Characteristics of Patients } & \multirow{2}{*}{$\begin{array}{l}\text { Asthma Group } \\
\text { Controlled asthma }\end{array}$} & \multirow{2}{*}{$\begin{array}{r}\text { Anemia Patients, } \\
\text { n (\%) } \\
9,171(4.51)\end{array}$} & \multirow{2}{*}{$\begin{array}{l}\text { OR }(95 \% \mathrm{Cl}) \\
\text { I [Reference] }\end{array}$} & \multirow[t]{2}{*}{$P$ value } & \multirow{2}{*}{$\begin{array}{r}\text { OR }_{\text {adj }}(\mathbf{9 5 \%} \mathrm{Cl}) \\
\mathrm{I}[\text { Reference }]\end{array}$} & \multirow[t]{2}{*}{$P$ value } \\
\hline Age & Children & & & & & & \\
\hline & $(<12$ years $)$ & Uncontrolled asthma & $346(14.76)$ & $3.67(3.27-4.12)$ & $<0.001$ & $2.65(2.16-3.24)$ & $<0.001$ \\
\hline & Adolescents & Controlled asthma & $647(2.11)$ & I [Reference] & & & \\
\hline & $(\geq 12,<18$ years $)$ & Uncontrolled asthma & $9(8.18)$ & $4.13(2.08-8.20)$ & $<0.001$ & $3.59(0.69-18.76)$ & 0.130 \\
\hline \multirow[t]{4}{*}{ Gender } & \multirow[t]{2}{*}{ Male } & Controlled asthma & $5,261(4.21)$ & I [Reference] & & & \\
\hline & & Uncontrolled asthma & $206(15.06)$ & $4.04(3.47-4.69)$ & $<0.001$ & $2.66(2.04-3.46)$ & $<0.001$ \\
\hline & \multirow[t]{2}{*}{ Female } & Controlled asthma & $4,557(4.18)$ & I [Reference] & & & \\
\hline & & Uncontrolled asthma & $149(13.72)$ & $3.64(3.06-4.34)$ & $<0.001$ & $2.61(1.92-3.56)$ & $<0.001$ \\
\hline \multirow[t]{4}{*}{ Insurance type } & \multirow[t]{2}{*}{ Health insurance } & Controlled asthma & $9649(4.20)$ & I [Reference] & & & \\
\hline & & Uncontrolled asthma & $348(14.53)$ & $3.87(3.45-4.35)$ & $<0.001$ & $2.64(2.16-3.24)$ & $<0.001$ \\
\hline & \multirow[t]{2}{*}{ Medical aid } & Controlled asthma & $169(3.77)$ & I [Reference] & & & \\
\hline & & Uncontrolled asthma & $7(11.86)$ & $3.44(1.54-7.69)$ & 0.003 & $2.41(0.60-9.63)$ & 0.214 \\
\hline
\end{tabular}

Abbreviation: $\mathrm{OR}$, odds ratio; $\mathrm{OR}_{\mathrm{ad}}$, odds ratio after adjusting with propensity score weighting.

asthma. ${ }^{30,31}$ Patients with higher IL-6 concentrations were reported to have severe asthma. ${ }^{32}$ The amount of TNF $\alpha$ was increased in the airways of patients with severe steroid-resistant asthma, but the results of TNF $\alpha$ inhibition for improving lung function were not consistent. ${ }^{33-35}$ Elderly or obese patients, who often have systemic inflammation, also showed more severe asthma. ${ }^{36,37}$ In addition, it has been suggested that various cytokines including TNF $\alpha$, IFN $\gamma$ or IL- 6 can contribute to anemia by reducing generation, lifespan or phagocytosis of erythrocytes, respectively. ${ }^{38-40}$. IL-6 was shown to stimulate the production of hepcidin by hepatocytes, which interferes with iron homeostasis. ${ }^{41,42}$ However, there are limitations in applying this potential role of inflammatory cytokines to pediatric population since pediatric diseases develop during maturation of tissues (ie lung) and immune system. Analyses of severe pediatric asthma are also very limited while the mechanism of asthma has been extensively studied for adults. Nonetheless, recent studies have suggested a presence of multiple cytokines in parallel with $\mathrm{Th} 2$ signatures in severe pediatric asthma. IFN $\gamma^{+} \mathrm{T}$ cells was found and inflammatory cytokines such as IL-1 and IL-6 was highly expressed in the lower airways of children with severe asthma. ${ }^{43,44}$ It has been shown that high level of serum IL-17 and IL- $17^{+} \mathrm{T}$ cells were associated with severe asthma in children. ${ }^{45,46}$ In addition, Caffarelli's study demonstrated that pediatric obese patients had a high prevalence of asthma, high hepcidin levels, and low iron levels. ${ }^{32}$ In obese children, inflammation is activated, which interferes with iron homeostasis, leading to anemia. ${ }^{47}$ Although it is possible that a heterogeneity of cytokines in severe asthma and inflammatory status may mediate anemia development in pediatric population, further studies are required to dissect the mechanisms with respect to immunophenotype of uncontrolled severe asthma with anemia.

A previous study reported an association between maternal anemia and increased asthma in children. ${ }^{48}$ The precise causality between anemia and asthma is not yet elucidated. However, at least in uncontrolled asthma patients, it is possible that the asthmatic condition allows several multiple mediators to aggravate AI and vice versa, implying a mutual association of anemia and asthmatic conditions. In this study, the increased risk of AI in the uncontrolled asthma group compared to controlled asthma showed the probability of this interconnection with anemia mediators.

In general, AI has different treatment approaches and responses compared to IDA. In particular, hepcidin was reported as an important indicator in the response to treatment for AI. ${ }^{4-51}$ No study has examined the hepcidin levels in asthma patients directly. We generally do not 
monitor asthma patients for anemia, and no guidelines recommend it. However, anemia negatively affects pediatric patients' growth and is associated with cognitive abnormalities and poor quality of life. ${ }^{10,11}$ In addition, in the case of AI, the treatment or control of the underlying disease takes precedence over the treatment of anemia by simply administering iron or EPO. ${ }^{12}$ In addition, it was reported that in patients with high hepcidin levels, an index that could distinguish between AI and IDA, was whether the administration of EPO or iron for the treatment of anemia resulted in low or no response. ${ }^{14,15}$ Therefore, it might be recommended to monitor and treat anemia since the incidence of anemia may increase in pediatric patients with uncontrolled asthma.

This study had several limitations. First, the assumption of the increased risk of AI in pediatric patients with uncontrolled asthma was indirectly shown by the association between uncontrolled asthma and IDA/AI. Although the increased pro-inflammatory cytokines in systemic inflammation could explain the relationship, the mechanism of action needs to be better understood. In addition, as patients diagnosed with IDA were included in the analysis, the effects of patients with isolated IDA cannot be ruled out in this condition. Third, it was a cross-sectional study, and thus, we could not determine a causative relationship between uncontrolled asthma and anemia directly, which prevented the demonstration of a possible mechanism of mutual interaction. Lastly, the limitation of classifying the control of asthma symptoms or the definition of anemia based on KCD-7 and/or prescribed drugs was that the lab values such as hepcidin were not confirmed and classified. Nevertheless, this study had several strengths. As far as we know, this was the first extensive study to show that uncontrolled asthma could be linked with IDA/AI in pediatric groups. This suggests that uncontrolled asthma could be associated with anemia, similar to other systemic inflammatory disorders. Moreover, we also used diagnostic code, not self-reports, for disease definitions, making the data for analysis more objective. Finally, the use of a large dataset could facilitate extrapolation into the entire Korean pediatric population.

\section{Conclusion}

Uncontrolled asthma was associated with an increased odds of anemia (IDA/AI) in pediatric patients enrolled in the National Health Insurance Service of Korea. Childhood asthma in school-age children was associated with higher odds of anemia. Further studies are needed to clarify the determinants of the association between uncontrolled asthma and anemia. Also, a distinction between IDA and AI may be required to better understand the cause of anemia in pediatric patients with inflammatory disease.

\section{Acknowledgments}

This work was supported by the National Research Foundation (NRF) of Korea grant funded by the Korea government (MSIT, Ministry of Science and ICT) (No. 2021R1F1A1059897).

\section{Disclosure}

The authors report no conflicts of interest related to this work.

\section{References}

1. Janus J, Moerschel SK. Evaluation of anemia in children. Am Fam Physician. 2010;81(12):1462-1471.

2. Kassebaum NJ, Jasrasaria R, Naghavi M, et al. A systematic analysis of global anemia burden from 1990 to 2010. Blood. 2014;123:615-624.

3. Steinbicker AU, Muckenthaler MU. Out of balance-systemic iron homeostasis in iron-related disorders. Nutrients. 2013;5:3034-3061.

4. Weiss G, Ganz T, Goodnough LT. Anemia of inflammation. Blood. 2019;133:40-50.

5. Nemeth E, Valore EV, Territo M, et al. Hepcidin, a putative mediator of anemia of inflammation, is a type II acute-phase protein. Blood. 2003;101:2461-2463.

6. Theurl I, Mattle V, Seifert M, et al. Dysregulated monocyte iron homeostasis and erythropoietin formation in patients with anemia of chronic disease. Blood. 2006;107:4142-4148.

7. Zarychanski R, Houston DS. Anemia of chronic disease: a harmful disorder or an adaptive, beneficial response? CMAJ. 2008; 179:333-337.

8. Hsu C, McCulloch CE, Curhan GC. Iron status and hemoglobin level in chronic renal insufficiency. $J$ Am Soc Nephrol. 2002;13:2783-2786.

9. Weiss G, Schett G. Anaemia in inflammatory rheumatic diseases. Nat Rev Rheumatol. 2013;9:205-215.

10. Abdel-Khalek MA, El-Barbary AM, Essa SA, et al. Serum hepcidin: a direct link between anemia of inflammation and coronary artery atherosclerosis in patients with rheumatoid arthritis. J Rheumatol. 2011;38:2153-2159.

11. Matsumoto M, Tsujino T, Lee-Kawabata M, et al. Iron regulatory hormone hepcidin decreases in chronic heart failure patients with anemia. Circ J. 2010;74:301-306.

12. Begum S, Latunde-Dada G. Anemia of Inflammation with An Emphasis on Chronic Kidney Disease. Nutrients. 2019;11:2424.

13. Wawer AA, Jennings A, Fairweather-Tait SJ. Iron status in the elderly: a review of recent evidence. Mech Ageing Dev. 2018;175:55-73.

14. Vanasse GJ, Berliner N. Anemia in elderly patients: an emerging problem for the 21st century. Hematology Am Soc Hematol Educ Program. 2010;2010:271-275.

15. Ganz T. Anemia of Inflammation. $N$ Engl $J$ Med. 2019;381:1148-1157.

16. Polin V, Coriat R, Perkins G, et al. Iron deficiency: from diagnosis to treatment. Dig Liver Dis. 2013;45:803-809. 
17. Hameed R, Peters RL, Field MJ. e al. Self-reported asthma prevalence and control in a population-based cohort of Australian school students aged 10-14 years. Arch Dis Child. 2019;104:612-613.

18. Hill DA, Grundmeier RW, Ram G, et al. The epidemiologic characteristics of healthcare provider-diagnosed eczema, asthma, allergic rhinitis, and food allergy in children: a retrospective cohort study. BMC Pediatr. 2016;16:133.

19. Karimkhani C, Dellavalle RP, Coffeng LE, et al. Global skin disease morbidity and mortality: an update from the global burden of disease study 2013. JAMA Dermatol. 2017;153:406-412.

20. Scott SP, Chen-Edinboro LP, Caulfield LE, et al. The impact of anemia on child mortality: an updated review. Nutrients. 2014;6:5915-5932.

21. Narla S, Silverberg JI. Association between atopic dermatitis and autoimmune disorders in US adults and children: a cross-sectional study. J Am Acad Dermatol. 2019;80:382-389.

22. Drury KE, Schaeffer M, Silverberg JI. Association between atopic disease and anemia in US children. JAMA Pediatr. 2016;170:29-34.

23. Rhew K, Oh JM. Association between atopic disease and anemia in pediatrics: a cross-sectional study. BMC Pediatr. 2019;19:455.

24. Rhew K, Brown JD, Oh JM. Atopic disease and anemia in Korean patients: cross-sectional study with propensity score analysis. Int J Environ Res Public Health. 2020;17:1978.

25. Kim L, Kim JA, Kim S. A guide for the utilization of health insurance review and assessment service national patient samples. Epidemiol Health. 2014;36:e2014008.

26. Rubin DB. Using propensity scores to help design observational studies: application to the tobacco litigation. Health Serv Outcomes Res Methodol. 2001;2:169-188.

27. Dugdale M. Anemia. Obstet Gynecol Clin North Am. 2001;28:363-381.

28. Republic of Korea Ministry of Health and Welfare. Medical Service Usage Status Report 2017. Available from: https://www.mohw.go.kr/ react/gm/sgm0704vw.jsp?PAR_MENU_ID=13\&MENU_ID= $13040801 \&$ page $=1 \&$ CONT_SEQ $=356233 \&$ PAR_CONT_SEQ $=$ 355637. (Accessed December 20, 2020.

29. Licari A, Castagnoli R, Brambilla I, et al. Asthma endotyping and biomarkers in childhood asthma. Pediatr Allergy Immunol Pulmonol. 2018;31:44-55.

30. Gibson PG, Simpson JL, Saltos N. Heterogeneity of airway inflammation in persistent asthma: evidence of neutrophilic inflammation and increased sputum interleukin-8. Chest. 2001;119:1329-1336.

31. Raundhal M, Morse C, Khare A, et al. High IFN- $\gamma$ and low SLPI mark severe asthma in mice and humans. $J$ Clin Invest. 2015;125:3037-3050.

32. Caffarelli C, Santamaria F, Cesari S, et al. Progress in pediatrics in 2011. Choices in Endocrinology, Gastroenterology, HematoOncology, Infectious Diseases, Otolaryngology, Pharmacotherapy and Respiratory Tract Illnesses Ital J Pediatr. 2012;38:23.

33. Berry MA, Hargadon B, Shelley M, et al. Evidence of a role of tumor necrosis factor alpha in refractory asthma. $N$ Engl J Med. 2006;354:697-708.

34. Wenzel SE, Barnes PJ, Bleecker ER, et al. A randomized, double-blind, placebo-controlled study of tumor necrosis factor-alpha blockade in severe persistent asthma. Am J Respir Crit Care Med. 2009;179:549-558.

Journal of Asthma and Allergy

\section{Publish your work in this journal}

The Journal of Asthma and Allergy is an international, peer-reviewed open-access journal publishing original research, reports, editorials and commentaries on the following topics: Asthma; Pulmonary physiology; Asthma related clinical health; Clinical immunology and the immunological basis of disease; Pharmacological interventions and

Submit your manuscript here: https://www.dovepress.com/journal-of-asthma-and-allergy-journa
35. Morjaria JB, Chauhan AJ, Babu KS, et al. The role of a soluble TNFalpha receptor fusion protein (etanercept) in corticosteroid refractory asthma: a double blind, randomised, placebo controlled trial. Thorax. 2008;63:584-591.

36. Jensen ME, Gibson PG, Collins CE, et al. Diet-induced weight loss in obese children with asthma: a randomized controlled trial. Clin Exp Allergy. 2013;43:775-784.

37. Zein JG, Dweik RA, Comhair SA, et al. Asthma is more severe in older adults. PLoS One. 2015;10:e133490.

38. Morceau F, Dicato M, Diederich M. Pro-inflammatory cytokine-mediated anemia: regarding molecular mechanisms of erythropoiesis. Mediators Inflamm. 2009;2009:405016.

39. Libregts SF, Gutiérrez L, de Bruin AM, et al. Chronic IFN- $\gamma$ production in mice induces anemia by reducing erythrocyte life span and inhibiting erythropoiesis through an IRF-1/PU.1 axis. Blood. 2011;118:2578-2588.

40. Milner JD, Orekov T, Ward JM, et al. Sustained IL-4 exposure leads to a novel pathway for hemophagocytosis, inflammation, and tissue macrophage accumulation. Blood. 2010;116:2476-2483.

41. Nemeth E, Rivera S, Gabayan V, et al. IL-6 mediates hypoferremia of inflammation by inducing the synthesis of the iron regulatory hormone hepcidin. J Clin Invest. 2004;113:1271-1276.

42. Rodriguez R, Jung CL, Gabayan V, et al. Hepcidin induction by pathogens and pathogen-derived molecules is strongly dependent on interleukin-6. Infect Immun. 2014;82:745-752.

43. Paul AGA, Muehling LM, Eccles JD, et al. T cells in severe childhood asthma. Clin Exp Allergy. 2019;49:564-581.

44. Wisniewski JA, Muehling LM, Eccles JD, et al. TH1 signatures are present in the lower airways of children with severe asthma, regardless of allergic status. J Allergy Clin Immunol. 2018;141:2048-2060.e13.

45. Chien JW, Lin CY, Yang KD, et al. Increased IL-17A secreting CD4+ $\mathrm{T}$ cells, serum IL-17 levels and exhaled nitric oxide are correlated with childhood asthma severity. Clin Exp Allergy. 2013;43:1018-1026.

46. Cai T, Qiu J, Ji Y, et al. IL-17-producing ST2(+) group 2 innate lymphoid cells play a pathogenic role in lung inflammation. J Allergy Clin Immunol. 2019;143:229-244.e9.

47. Hutchinson C. A review of iron studies in overweight and obese children and adolescents: a double burden in the young? Eur J Nutr. 2016;55:2179-2197.

48. Triche EW, Lundsberg LS, Wickner PG, et al. Association of maternal anemia with increased wheeze and asthma in children. Ann Allergy Asthma Immunol. 2011;106:131-139.e1.

49. Sanad M, Osman M, Gharib A. Obesity modulate serum hepcidin and treatment outcome of iron deficiency anemia in children: a case control study. Ital J Pediatr. 2011;37:34.

50. Theurl M, Nairz M, Schroll A, et al. Hepcidin as a predictive factor and therapeutic target in erythropoiesis-stimulating agent treatment for anemia of chronic disease in rats. Haematologica. 2014;99:1516-1524.

51. Bregman DB, Morris D, Koch TA, et al. Hepcidin levels predict nonresponsiveness to oral iron therapy in patients with iron deficiency anemia. Am J Hematol. 2013;88:97-101.

new therapies. The manuscript management system is completely online and includes a very quick and fair peer-review system, which is all easy to use. Visit http://www.dovepress.com/testimonials.php to read real quotes from published authors. 